\title{
SIR LUDWIG GUTTMANN: FROM A GRATEFUL PATIENT
}

\author{
By Rev. Albert H. Bull \\ Great Britain
}

It was February 1945 that I was wheeled on a stretcher into Ward 2X at Stoke Mandeville Hospital and for the first time met the man who was to bring back the word hope into my present life.

Some I 8 months previously, in July I943, I had been taking part as an Army Chaplain in the invasion of Sicily when a shell hit the landing craft from which I had just jumped and I became, something I had never heard of before, a paraplegic. I spent 4 months in hospitals abroad, one in Tripoli and the other in Alexandria. The heat was tropical and I developed bed sores and infections. In Tripoli I believe penicillin was being used for the first time in quantity.

I then got home to England. A hospital had to be found somewhere near my home which could cope. Later they told me they had protested as they had no knowledge of how to deal with paraplegia. It was a sector hospital at St Thomas; the doctors and nurses were kindness itself, but in the state I was there was little hope of ever leaving my bed and getting around even in a wheelchair.

Then I read in The Times a letter which said something of the treatment of paraplegia at Stoke Mandeville. I got in touch with the writer and he said I should go to Stoke. I asked the doctors but they had never heard of Dr Guttmann or Stoke Mandeville. Anyhow I managed to get myself transferred there.

What a transformation! I think the word hope sums it up. I heard of the possibility of healing bed sores; the possibility of getting rid of suprapubic catheters; the possibility of getting control of bowels; then the possibility of getting into a wheelchair and as time went by the possibility of getting home and even back to work.

Tragedy though paraplegia must always be, here at Stoke Mandeville was the hope of still living a full life. How was this all happening-it revolved around one man, Ludwig Guttmann. In those early days he was sometimes the only doctor, he worked from morning till night, often all through the night if a patient was very ill. He lived at the hospital sometimes going home to Oxford at weekends. At night as the lights went out in the wards I could often see him still working away in the little office he had in the ward opposite.

There was little set treatment for paraplegia. Dr Guttmann with the help of his staff and patients was feeling his way, problems and difficulties had to be surmounted. For example, there was no folding wheel-chair manufactured in England and it was impossible to import the Everest and Jennings from America. But every problem to him was a challenge and every problem had to be overcome.

$\mathrm{He}$ drove his staff and patients ruthlessly-some could not take it and were treated with short shrift. But as I look back I know we needed to be bullied. It is so easy to sit back, feel sorry for yourself and allow others to do everything for you.

Dr Guttmann lived, talked and must have dreamt paraplegia. I remember a local doctor told me how, when he invited him to dinner, he was regaled throughout the evening with a lecture on paraplegia.

He loved to gather great crowds around him on his ward rounds. They would take hours as he told the history of each patient. I was always terribly embarrassed 
as he would insist on relating the awful state of my bowels when first I arrived at Stoke Mandeville. Not only were there morning rounds but in the evening he would come round the wards again, a social round, and we would chat together about our hopes and aspirations.

In those early days few new cases of paraplegia ever arrived in the hospital. Nearly everyone had been in other hospitals where they had acquired bed sores and various infections. Stoke had to clear up the mess. Many times did I see Sir Ludwig rage up and down the ward horrified at the bed sores of some recently admitted patient-sad to say this kind of thing is still happening.

I must tell, too, of his many acts of kindness. Let me quote but one of them. On the first Remembrance Sunday after the War, I was invited to preach at the British Legion service at Weston Turville, a little village near Aylesbury. This was to be the first time I had taken part in a Church service outside the hospital since being wounded. I went in a small ambulance as the wheel-chairs would not go into a car. Sir Ludwig, a Jew, and always proud of it, happily came along to support and encourage me, such was his kindness.

Civil servants must have quivered when they heard his name. No one, I should think, has ever cut away so much red tape. Somehow or other he got the money for a swimming pool at the hospital when no Government grants of any sort were available. Who, but he, could have persuaded the Ministry of Pensions to accommodate once a year, dozens, then hundreds of paraplegics when his famous games began. I can remember the first games, a friendly affair with men and women from different parts of the country. Then he began to talk about International games and Olympics and everyone laughed and thought it impossible.

I could go on and on about my friend who put the word hope back into the lives of hundreds of paraplegics.

I was wounded at the age of 32 and now I am 66, more or less retired, after 35 years of paraplegia. He is 80 and like Moses of old 'his eye is not dim nor his natural force abated'. May God bless him and give him many happy returns. 